\title{
Variants in the CXCL12 gene was associated with coronary artery disease susceptibility in Chinese Han population
}

\author{
Junbo Zhang ${ }^{1, *}$, Huijun $\mathrm{Ma}^{2,}$, , Jie Gao ${ }^{3}$, Shu Kong ${ }^{4}$, Jiangtao You ${ }^{5}$ and Ying Sheng ${ }^{1}$ \\ ${ }^{1}$ Department of Peripheral Vascular, First Affiliated Hospital of Xi'an Jiaotong University, Xi'an 710061, China \\ ${ }^{2}$ Department of Cardiology, The First Hospital of Xi'an, Xi'an 710002, China \\ ${ }^{3}$ Cadre Ward of the Second Affiliated Hospital of Xi'an Jiaotong University, Xi'an 710004, China \\ ${ }^{4}$ Institute of Medical Engineering, Medical School of Xi'an Jiaotong University, Xi'an 710061, China \\ ${ }^{5}$ Department of Thoracic Surgery, First Affiliated Hospital of Xi'an Jiaotong University, Xi'an 710061, China \\ *Junbo Zhang and Huijun Ma contributed equally to this paper \\ Correspondence to: Ying Sheng, email: drshengying@163.com \\ Keywords: CXCL12, coronary heart disease, gene polymorphisms, case-control study \\ Received: November 01, $2016 \quad$ Accepted: February 28, $2017 \quad$ Published: April 18, 2017 \\ Copyright: Zhang et al. This is an open-access article distributed under the terms of the Creative Commons Attribution License 3.0 \\ (CC BY 3.0), which permits unrestricted use, distribution, and reproduction in any medium, provided the original author and source \\ are credited.
}

\section{ABSTRACT}

Background: Coronary artery disease (CAD) is one of the most serious diseases all around the world. Previous studies have shown the function of CXCL12 in the process of atherosclerosis. The aim of this research is to examine whether variants of CXCL12 contribute to CAD.

Materials and Methods: To examine whether variants of CXCL12 contribute to CAD, we selected 6 single nucleotide polymorphisms (SNPs) of CXCL12, and genotyped by Sequenom MassARRAY technology in 597 CAD patients and 685 healthy control. Odds ratio (OR) and $95 \%$ confidence intervals (CIs) were calculated by unconditional logistic regression adjusted for age and gender. We also analysis the differences in continuous variables among the subjects with three genotypes of related genes were assessed using the ANOVA.

Results: We found significant differences in apoB concentrations with rs1065297 and rs10793538 different genotype. In the allele model, rs1065297, rs266089 and rs10793538 in CXCL12 gene associated with the risk of CAD. Stratified according to gender, rs266089 and rs2839693 in CXCL12 gene were associated with the risk of CAD in men, while rs1065297 and rs10793538 in CXCL12 gene were associated with the risk of CAD in women. Stratified according to age, rs197452 decreased the risk of CAD in less than $\mathbf{5 0}$ years old group. While in more than $\mathbf{5 0}$ years old group, not find significant results. Haplotype analysis shown that haplotype "TGCC" in the block increased CAD risk (OR=1.26, 95\%CI: $1.00-1.58, p=0.046)$.

Conclusion: This study provides an evidence for polymorphism of CXCL12 gene associated with CAD development in Chinese Han population.

\section{INTRODUCTION}

Coronary artery disease (CAD), also named as coronary heart disease (CHD) or ischaemic heart disease (IHD), has become one of the most common cause of morbidity and mortality in cardiovascular diseases (CVDs) all around the world, especially in the industrial countries [1]. Coronary heart disease (CHD) is caused by obstruction of epicardial coronary artery that supplies blood and oxygen to the heart. Multiple factors, such as lifestyle and environmental factors, play critical roles in the occurrence and progression of CHD. The characteristic pathological changes of CAD is atherosclerosis that results from the endothelial injury or functional disorder, which is triggered by the abnormal accumulation of lipoproteins in the intima [2]. Plenty of cells such as T cells, dendritic 
Table 1: Basic information of case and control groups

\begin{tabular}{|c|c|c|c|c|c|}
\hline & \multicolumn{2}{|c|}{ Case } & \multicolumn{2}{|c|}{ Control } & \multirow{2}{*}{$p$} \\
\hline & female & male & female & male & \\
\hline$<55$ & 41 & 124 & 214 & 184 & \\
\hline$\geq 55$ & 180 & 252 & 86 & 101 & \\
\hline total & \multicolumn{2}{|c|}{597} & \multicolumn{2}{|c|}{685} & 0.014 \\
\hline Mean age & \multicolumn{2}{|c|}{61.44} & \multicolumn{2}{|c|}{48.59} & $p<0.001$ \\
\hline $\operatorname{ALT}(\mathrm{U} / \mathrm{L})$ & \multicolumn{2}{|c|}{$31.15 \pm 2.11$} & & & \\
\hline AST (U/L) & \multicolumn{2}{|c|}{$36.41 \pm 2.93$} & & & \\
\hline GGT (U/L) & \multicolumn{2}{|c|}{$44.65 \pm 3.77$} & & & \\
\hline $\operatorname{TP}(\mathrm{g} / \mathrm{L})$ & \multicolumn{2}{|c|}{$66.39 \pm 0.3$} & & & \\
\hline GLU (mmol/L) & \multicolumn{2}{|c|}{$6.34 \pm 0.11$} & & & \\
\hline $\mathrm{TG}(\mathrm{mmol} / \mathrm{L})$ & \multicolumn{2}{|c|}{$1.8 \pm 0.07$} & & & \\
\hline $\mathrm{TC}(\mathrm{mmol} / \mathrm{L})$ & \multicolumn{2}{|c|}{$4.09 \pm 0.06$} & & & \\
\hline HDL-C $(\mathrm{mmol} / \mathrm{L})$ & \multicolumn{2}{|c|}{$1.13 \pm 0.01$} & & & \\
\hline LDL-C $(\mathrm{mmol} / \mathrm{L})$ & \multicolumn{2}{|c|}{$1.92 \pm 0.04$} & & & \\
\hline APOA1 (g/L) & \multicolumn{2}{|c|}{$1.26 \pm 0.01$} & & & \\
\hline APOB $(g / L)$ & \multicolumn{2}{|c|}{$1 \pm 0.02$} & & & \\
\hline $\mathrm{Lp}(\mathrm{a})(\mathrm{mg} / \mathrm{L})$ & \multicolumn{2}{|c|}{$239.2 \pm 12.14$} & & & \\
\hline
\end{tabular}

ALT: alanine aminotransferase, AST: aspartate aminotransferase, GGT: gamma-glutamyl transpeptidase, TP: total protein, GLU: glucose, TG: triglyceride, TC: total cholesterol, HDL: high-density lipoprotein, LDL: low-density lipoprotein, apoA: apolipoprotein A, apoB: apolipoprotein B, LP(a): lipoprotein.

$p<0.05$, statistical significance.

cells, neutrophils and macrophages are also involved into the process of the disease. Traditional environmental risk factor for CAD contains tobacco smoking, hypertension, diabetes or hyperglycemia, hyperlipidemia especially high levels of LDL and obesity or overweight [3]. There is a growing worldwide awareness of that heritable factors play an important role in the progress of atherosclerosis [4] and relatively a great many genome-wide association studies (GWAS) have confirmed the effect of genes in CAD [5-7].

Atherosclerosis is actually a chronic inflammatory reaction in blood vessels and includes two remarkable steps, foam cell formation and smooth muscle cell recruitment. Chemokine (C-X-C motif) ligand 12 (CXCL12), also called stromal cell-derived factor-1 (SDF1 ), is one of the members of CXC chemokine family [8] and mostly known for its crucial role in the accumulation of smooth muscle progenitor cells (SPCs) [9]. It will trigger MAPK and PI3K signal pathway [10] by binding to a $\mathrm{G}$ protein-coupled receptor, $\mathrm{CXCR} 4$, and contribute to macrophage migration which results from lipid accumulation especially low-density lipoprotein (LDL) [11]. Additionally, it is identified that different single nucleotide polymorphisms (SNPs) of CXCL12 participates in various disease such as neck and head squamous cell carcinoma [12], myelodysplastic syndromes [13], multiple sclerosis [14], etc. Here, we choose six SNPs (rs1065297, rs1801157, rs266089, rs197452, rs2839693 and rs10793538) of CXCL12 to explore which SNPs are associated with the risk of CAD.

\section{RESULTS}

After all the experiments and data compilation, 597 cases (376 males and 221 females) and 685 controls (385 males and 300 females) were included in the final analysis. As listed in Table 1, the mean age of cases is 61.44 while the control group is 48.59 . The $\mathrm{p}$ value of age and sex were less than 0.001 and 0.014 , respectively. Clinical and biochemical index of information in CAD patients in the Table 1, including ALT, AST, GGT, TP, GLU, TG, TC, HDL, LDL, apoA, apoB, LP(a), ect.

The basic characteristics of the study subjects stratified by different genotype are shown in Table 2 . We found significant differences in apoB concentrations with rs 1065297 and rs10793538 different genotype. For rs1065297, the mean serum apoB concentration was 1.03 for the GG genotype (highest), 0.76 for the GA 
Table 2: Characteristics of the subjects with 3 different genotypes

\begin{tabular}{|c|c|c|c|c|c|}
\hline \multirow{2}{*}{$\frac{\text { SNP }}{\text { rs1065297 }}$} & & \multicolumn{3}{|c|}{ Genotype } & \multirow[t]{2}{*}{$\mathbf{p}$} \\
\hline & & GG & GA & $\mathrm{AA}$ & \\
\hline \multirow[t]{2}{*}{ LDL-C } & sample size & 1 & 27 & 402 & \\
\hline & Mean \pm std & 2.43 & $1.53 \pm 0.65$ & $1.94 \pm 0.84$ & 0.036 \\
\hline \multirow[t]{2}{*}{ apoB } & sample size & 1 & 27 & 401 & \\
\hline & Mean \pm std & 1.03 & $0.76 \pm 0.31$ & $1.01 \pm 0.37$ & 0.003 \\
\hline rs1801157 & & $\mathrm{CC}$ & $\mathrm{CT}$ & $\mathrm{TT}$ & \\
\hline \multirow[t]{2}{*}{$\mathrm{TP}$} & sample size & 272 & 148 & 22 & \\
\hline & Mean \pm std & $67.03 \pm 6.33$ & $65.44 \pm 6.26$ & $64.83 \pm 6.47$ & 0.023 \\
\hline rs10793538 & & TT & TA & $\mathrm{AA}$ & \\
\hline \multirow[t]{2}{*}{ apoB } & sample size & 1 & 26 & 402 & \\
\hline & Mean \pm std & 1.03 & $0.76 \pm 032$ & $1.01 \pm 0.37$ & 0.004 \\
\hline
\end{tabular}

$p<0.05$, statistical significance.

Table 3: Basic SNPs in CXCL12 gene summary of all study participants

\begin{tabular}{|c|c|c|c|c|c|c|c|c|c|c|}
\hline \multirow{2}{*}{ SNP } & \multirow{2}{*}{$\begin{array}{c}\text { Base/ } \\
\text { Change }\end{array}$} & \multicolumn{2}{|c|}{ MAF } & \multirow{2}{*}{$\begin{array}{c}\text { HWE } \\
p\end{array}$} & \multicolumn{2}{|l|}{ Total } & \multicolumn{2}{|l|}{ Male } & \multicolumn{2}{|c|}{ Female } \\
\hline & & Case & Control & & OR(95\%CI) & $p$ & OR(95\%CI) & $p$ & $\mathrm{OR}(95 \% \mathrm{CI})$ & $p$ \\
\hline rs1065297 & $\mathrm{G} / \mathrm{A}$ & 0.046 & 0.07 & 0.04 & $0.64(0.46-0.90)$ & 0.01 & $\begin{array}{c}0.74(0.48- \\
1.14)\end{array}$ & 0.166 & $\begin{array}{c}0.51(0.29- \\
0.89)\end{array}$ & 0.017 \\
\hline rs1801157 & $\mathrm{T} / \mathrm{C}$ & 0.217 & 0.21 & 0.644 & $1.04(0.86-1.26)$ & 0.655 & $1(0.78-1.27)$ & 0.999 & $\begin{array}{c}1.1(0.81- \\
1.49)\end{array}$ & 0.54 \\
\hline rs266089 & $\mathrm{A} / \mathrm{G}$ & 0.19 & 0.16 & 0.201 & $1.23(1.00-1.51)$ & 0.046 & $\begin{array}{c}1.46(1.11- \\
1.91)\end{array}$ & 0.006 & $\begin{array}{c}0.99(0.72- \\
1.36)\end{array}$ & 0.938 \\
\hline rs 197452 & $\mathrm{~T} / \mathrm{C}$ & 0.116 & 0.116 & 0.852 & $1.00(0.78-1.27)$ & 0.97 & $0.96(0.7-1.31)$ & 0.781 & $\begin{array}{c}1.05(0.72- \\
1.53)\end{array}$ & 0.808 \\
\hline rs2839693 & $\mathrm{T} / \mathrm{C}$ & 0.168 & 0.145 & 0.642 & $1.19(0.96-1.47)$ & 0.113 & $\begin{array}{c}1.44(1.09- \\
1.89)\end{array}$ & 0.01 & $\begin{array}{c}0.89(0.63- \\
1.26)\end{array}$ & 0.529 \\
\hline rs10793538 & $\mathrm{T} / \mathrm{A}$ & 0.046 & 0.068 & 0.119 & $\begin{array}{c}0.669(0.47- \\
0.93)\end{array}$ & 0.016 & $0.77(0.5-1.2)$ & 0.249 & $\begin{array}{c}0.52(0.3- \\
0.92)\end{array}$ & 0.019 \\
\hline
\end{tabular}

$p<0.01$, statistical significance for HWE

$p<0.05$, statistical significance.

genotype (lowest), 1.01 for AA genotype $(p=0.003)$. For rs10793538, the mean serum apoB concentration of TT, TA and AA is 1.03, 0.76, and 1.01 respectively.

The allele information including MAF, HWE, OR etc. were demonstrated in Table 3. In the allele model, rs1065297, rs266089 and rs10793538 in CXCL12 gene associated with the risk of CAD. Among them CXCL12 rs1065297 and rs10793538 decreased CAD risk (rs 1065297: $\mathrm{OR}=0.64,95 \% \mathrm{CI}$ : 0.46-0.90, $p=0.010$; rs 10793538: $\mathrm{OR}=0.67,95 \% \mathrm{CI}: 0.47-0.93, p=0.016)$. Rs266089 in CXCL12 gene increased the risk of CAD
$(\mathrm{OR}=1.23, \quad 95 \% \mathrm{CI}: 1.00-1.51, \quad p=0.046)$. Stratified according to gender, in the allele model, rs266089 and rs2839693 in CXCL12 gene were associated with the risk of CAD in men, while rs1065297 and rs10793538 in CXCL12 gene were associated with the risk of CAD in women.

We further explored the relationship between CXCL12 gene and CAD in four genetic models (genotype, dominant, recessive and log-additive model) by unconditional logistic regression (Table 4). Results show that the odds of having CAD would be 1.30 -fold $(95 \% \mathrm{CI}$ : 
Table 4: Associations between CXCL12 SNPs and CAD

\begin{tabular}{|c|c|c|c|c|c|c|c|c|}
\hline \multirow[t]{2}{*}{ SNP } & \multirow[t]{2}{*}{ Model } & \multirow[t]{2}{*}{ Genotype } & \multirow[t]{2}{*}{ control } & \multirow[t]{2}{*}{ case } & \multicolumn{2}{|c|}{ Crude analysis } & \multicolumn{2}{|c|}{$\begin{array}{c}\text { adjusted by age and } \\
\text { gender }\end{array}$} \\
\hline & & & & & OR $(95 \%$ CI $)$ & $p$-value & OR $(95 \%$ CI $)$ & $p$-value \\
\hline \multirow[t]{8}{*}{ rs 266089} & Codominant & $\mathrm{G} / \mathrm{G}$ & $487(71.2 \%)$ & $\begin{array}{c}391 \\
(65.5 \%)\end{array}$ & 1 & 0.086 & 1 & 0.18 \\
\hline & & $\mathrm{G} / \mathrm{A}$ & $175(25.6 \%)$ & $\begin{array}{c}185 \\
(31 \%)\end{array}$ & $\begin{array}{c}1.32(1.03- \\
1.68)\end{array}$ & & $\begin{array}{c}1.31(0.97- \\
1.75)\end{array}$ & \\
\hline & & $\mathrm{A} / \mathrm{A}$ & $22(3.2 \%)$ & $\begin{array}{c}21 \\
(3.5 \%)\end{array}$ & $\begin{array}{c}1.19(0.64- \\
2.19)\end{array}$ & & $\begin{array}{l}0.91(0.43- \\
1.94)\end{array}$ & \\
\hline & Dominant & $\mathrm{G} / \mathrm{G}$ & $487(71.2 \%)$ & $\begin{array}{c}391 \\
(65.5 \%)\end{array}$ & 1 & 0.028 & 1 & 0.11 \\
\hline & & $\mathrm{G} / \mathrm{A}-\mathrm{A} / \mathrm{A}$ & $197(28.8 \%)$ & $\begin{array}{c}206 \\
(34.5 \%)\end{array}$ & $\begin{array}{c}1.30(1.03- \\
1.65)\end{array}$ & & $\begin{array}{l}1.26(0.95- \\
1.67)\end{array}$ & \\
\hline & Recessive & G/G-G/A & $662(96.8 \%)$ & $\begin{array}{c}576 \\
(96.5 \%)\end{array}$ & 1 & 0.77 & 1 & 0.65 \\
\hline & & $\mathrm{A} / \mathrm{A}$ & $22(3.2 \%)$ & $\begin{array}{c}21 \\
(3.5 \%)\end{array}$ & $\begin{array}{c}1.10(0.60- \\
2.02)\end{array}$ & & $\begin{array}{c}0.84(0.40- \\
1.78)\end{array}$ & \\
\hline & $\begin{array}{l}\text { Log- } \\
\text { additive }\end{array}$ & --- & --- & --- & $\begin{array}{c}1.23(1.00- \\
1.50)\end{array}$ & 0.048 & $\begin{array}{c}1.17(0.91- \\
1.49)\end{array}$ & 0.22 \\
\hline \multirow[t]{8}{*}{ rs10793538 } & Codominant & $\mathrm{A} / \mathrm{A}$ & $594(87.2 \%)$ & $\begin{array}{c}544 \\
(91.1 \%)\end{array}$ & 1 & 0.06 & 1 & 0.61 \\
\hline & & $\mathrm{T} / \mathrm{A}$ & $81(11.9 \%)$ & $\begin{array}{c}51 \\
(8.5 \%)\end{array}$ & $\begin{array}{c}0.69(0.48- \\
0.99)\end{array}$ & & $\begin{array}{l}0.91(0.58- \\
1.41)\end{array}$ & \\
\hline & & $\mathrm{T} / \mathrm{T}$ & $6(0.9 \%)$ & $2(0.3 \%)$ & $\begin{array}{c}0.36(0.07- \\
1.81)\end{array}$ & & $\begin{array}{l}0.40(0.05- \\
3.21)\end{array}$ & \\
\hline & Dominant & $\mathrm{A} / \mathrm{A}$ & $594(87.2 \%)$ & $\begin{array}{c}544 \\
(91.1 \%)\end{array}$ & 1 & 0.025 & 1 & 0.54 \\
\hline & & $\mathrm{T} / \mathrm{A}-\mathrm{T} / \mathrm{T}$ & $87(12.8 \%)$ & $\begin{array}{c}53 \\
(8.9 \%)\end{array}$ & $\begin{array}{c}0.67(0.46- \\
0.95)\end{array}$ & & $\begin{array}{c}0.87(0.57- \\
1.35)\end{array}$ & \\
\hline & Recessive & $\mathrm{A} / \mathrm{A}-\mathrm{T} / \mathrm{A}$ & $675(99.1 \%)$ & $\begin{array}{c}595 \\
(99.7 \%)\end{array}$ & 1 & 0.2 & 1 & 0.37 \\
\hline & & $\mathrm{T} / \mathrm{T}$ & $6(0.9 \%)$ & $2(0.3 \%)$ & $\begin{array}{c}0.38(0.08- \\
1.88)\end{array}$ & & $\begin{array}{c}0.40(0.05- \\
3.25)\end{array}$ & \\
\hline & $\begin{array}{l}\text { Log- } \\
\text { additive }\end{array}$ & --- & --- & --- & $\begin{array}{c}0.67(0.48- \\
0.94)\end{array}$ & 0.018 & $\begin{array}{c}0.86(0.57- \\
1.28)\end{array}$ & 0.45 \\
\hline
\end{tabular}

$p<0.05$, statistical significance.

1.30-1.65, $p=0.028$ ) with GA-AA genotype, compared with the subjects with the homozygous GG genotype in the dominant model. A log-additive model revealed a potential association with $\mathrm{CAD}(\mathrm{OR}=0.67,95 \% \mathrm{CI}$ : 0.48 $0.94, p=0.018$ ). But after adjusting by gender and age, we found no association between the SNPs and CAD.

Stratified according to gender, we found that under the dominant model rs266089 "GA-AA" genotype and rs2839693 "CT-TT” genotype increased the risk of CAD in men (rs266089: $\mathrm{OR}=1.54,95 \% \mathrm{CI}: 1.13-2.10, p=0.006$; rs2839693: OR=1.51, 95\%CI: $1.10-2.07, p=0.010$ ) (Table 5). While in the women, rs1065297 and rs10793538 decreased the CAD risk under the log-additive model (rs1065297: $\mathrm{OR}=0.52,95 \% \mathrm{CI}: 0.30-0.91, p=0.021$; rs 10793538: $\mathrm{OR}=0.53,95 \% \mathrm{CI}: 0.31-0.93, \quad p=0.027$ ) (Table 5).

Stratified according to age, we found that under the log-additive model, rs197452 decreased the risk of 
Table 5: The relationship between $C X C L 12$ genetic polymorphism and CAD was analyzed according to the gender stratification

\begin{tabular}{|c|c|c|c|c|c|c|c|c|c|}
\hline & \multirow{2}{*}{ SNP } & \multirow{2}{*}{ Model } & \multirow{2}{*}{ Genotype } & \multirow{2}{*}{ control } & \multirow{2}{*}{ case } & \multicolumn{2}{|c|}{ Crude analysis } & \multicolumn{2}{|c|}{ adjusted by age } \\
\hline & & & & & & OR $(95 \%$ CI $)$ & P-value & OR $(95 \%$ CI) & P-value \\
\hline \multirow[t]{16}{*}{ Male } & rs266089 & Genotype & GG & 284 & 242 & 1 & 0.022 & 1 & 0.054 \\
\hline & & & GA & 92 & 119 & $1.52(1.10-2.10)$ & 0.011 & $1.57(1.09-2.28)$ & 0.017 \\
\hline & & & $\mathrm{AA}$ & 10 & 18 & $1.76(0.78-3.99)$ & 0.176 & $1.34(0.51-3.50)$ & 0.551 \\
\hline & & Dominant & GG & 284 & 242 & 1 & 0.006 & 1 & 0.016 \\
\hline & & & GA-AA & 102 & 137 & $1.54(1.13-2.10)$ & & $1.55(1.08-2.21)$ & \\
\hline & & Recessive & GG-GA & 376 & 361 & 1 & 0.282 & 1 & 0.733 \\
\hline & & & $\mathrm{AA}$ & 10 & 18 & $1.56(0.69-3.52)$ & & $1.18(0.45-3.07)$ & \\
\hline & & $\begin{array}{c}\text { Log- } \\
\text { additive }\end{array}$ & --- & --- & --- & $1.45(1.11-1.19)$ & 0.007 & $1.41(1.04-1.93)$ & 0.029 \\
\hline & rs2839693 & Genotype & $\mathrm{CC}$ & 292 & 252 & 1 & 0.036 & 1 & 0.19 \\
\hline & & & CT & 86 & 111 & $1.50(1.01-2.08)$ & 0.016 & $1.40(0.96-2.04)$ & \\
\hline & & & TT & 9 & 13 & $1.67(0.70-3.98)$ & 0.244 & $1.45(0.52-4.08)$ & 0.477 \\
\hline & & Dominant & $\mathrm{CC}$ & 292 & 252 & 1 & 0.01 & 1 & 0.069 \\
\hline & & & CT-TT & 95 & 124 & $1.51(1.10-2.07)$ & & $1.40(0.97-2.02)$ & \\
\hline & & Recessive & CC-CT & 378 & 363 & 1 & 0.353 & 1 & 0.584 \\
\hline & & & $\mathrm{TT}$ & 9 & 13 & $1.50(0.64-3.56)$ & & $1.33(0.48-3.73)$ & \\
\hline & & $\begin{array}{c}\text { Log- } \\
\text { additive }\end{array}$ & --- & --- & --- & $1.42(1.08-1.87)$ & 0.012 & $1.33(0.97-1.83)$ & 0.079 \\
\hline \multirow[t]{16}{*}{ Female } & rs1065297 & Genotype & $\mathrm{AA}$ & 257 & 203 & 1 & 0.17 & 1 & 0.614 \\
\hline & & & $\mathrm{AG}$ & 40 & 18 & $0.57(0.32-1.02)$ & 0.06 & $0.68(0.32-1.45)$ & 0.323 \\
\hline & & & GG & 3 & 0 & / & / & / & l \\
\hline & & Dominant & $\mathrm{AA}$ & 257 & 203 & 1 & 0.032 & 1 & 0.244 \\
\hline & & & AG-GG & 43 & 18 & $0.53(0.3-0.95)$ & & $0.64(0.3-1.35)$ & \\
\hline & & Recessive & AA-AG & 297 & 221 & 1 & / & 1 & / \\
\hline & & & GG & 3 & 0 & / & & l & \\
\hline & & $\begin{array}{c}\text { Log- } \\
\text { additive }\end{array}$ & --- & --- & --- & $0.52(0.3-0.91)$ & 0.021 & $0.63(0.31-1.28)$ & 0.199 \\
\hline & rs10793538 & Genotype & AA & 258 & 203 & 1 & 0.206 & 1 & 0.787 \\
\hline & & & AT & 39 & 18 & $0.59(0.33-1.06)$ & 0.075 & $0.77(0.36-1.63)$ & 0.489 \\
\hline & & & $\mathrm{TT}$ & 3 & 0 & / & / & l & l \\
\hline & & Dominant & $\mathrm{AA}$ & 258 & 203 & 1 & 0.041 & 1 & 0.379 \\
\hline & & & AT-TT & 42 & 18 & $0.54(0.3-0.97)$ & & $0.72(0.34-1.51)$ & \\
\hline & & Recessive & AA-AT & 297 & 221 & 1 & / & 1 & l \\
\hline & & & TT & 3 & 0 & / & & 1 & \\
\hline & & $\begin{array}{l}\text { Log- } \\
\text { additive }\end{array}$ & -- & --- & --- & $0.53(0.31-0.93)$ & 0.027 & $0.69(0.34-1.4)$ & 0.307 \\
\hline
\end{tabular}

$p<0.05$, statistical significance. 
Table 6: The relationship between $C X C L 12$ genetic polymorphism and CAD was analyzed according to the age stratification

\begin{tabular}{|c|c|c|c|c|c|c|c|c|c|}
\hline & \multirow{2}{*}{ SNP } & \multirow{2}{*}{ Model } & \multirow{2}{*}{ Genotype } & \multirow{2}{*}{ control } & \multirow{2}{*}{ case } & \multicolumn{2}{|c|}{ Crude analysis } & \multicolumn{2}{|c|}{ adjusted by gender } \\
\hline & & & & & & OR $(95 \%$ CI $)$ & $p$-value & OR $(95 \%$ CI $)$ & $p$-value \\
\hline \multirow{8}{*}{$<55$} & \multirow[t]{8}{*}{ rs197452 } & \multirow[t]{3}{*}{ Codominant } & $\mathrm{C} / \mathrm{C}$ & $393(78.9 \%)$ & $\begin{array}{c}141 \\
(85.5 \%)\end{array}$ & 1 & 0.073 & 1 & 0.081 \\
\hline & & & $\mathrm{C} / \mathrm{T}$ & $101(20.3 \%)$ & $24(14.6 \%)$ & $\begin{array}{c}0.66(0.41- \\
1.08)\end{array}$ & & $\begin{array}{c}0.68(0.42- \\
1.11)\end{array}$ & \\
\hline & & & $\mathrm{T} / \mathrm{T}$ & $4(0.8 \%)$ & $0(0 \%)$ & $\begin{array}{c}0.00(0.00- \\
\text { NA) }\end{array}$ & & $\begin{array}{c}0.00(0.00- \\
\text { NA) }\end{array}$ & \\
\hline & & \multirow[t]{2}{*}{ Dominant } & $\mathrm{C} / \mathrm{C}$ & $393(78.9 \%)$ & $\begin{array}{c}141 \\
(85.5 \%)\end{array}$ & 1 & 0.06 & 1 & 0.077 \\
\hline & & & $\mathrm{C} / \mathrm{T}-\mathrm{T} / \mathrm{T}$ & $105(21.1 \%)$ & $24(14.6 \%)$ & $\begin{array}{c}0.64(0.39- \\
1.03)\end{array}$ & & $\begin{array}{c}0.65(0.40- \\
1.06)\end{array}$ & \\
\hline & & \multirow[t]{2}{*}{ Recessive } & $\mathrm{C} / \mathrm{C}-\mathrm{C} / \mathrm{T}$ & $494(99.2 \%)$ & $165(100 \%)$ & 1 & 0.13 & 1 & 0.11 \\
\hline & & & $\mathrm{T} / \mathrm{T}$ & $4(0.8 \%)$ & $0(0 \%)$ & $\begin{array}{c}0.00(0.00- \\
\text { NA) }\end{array}$ & & $\begin{array}{c}0.00(0.00- \\
\text { NA) }\end{array}$ & \\
\hline & & Log-additive & --- & --- & --- & $\begin{array}{c}0.63(0.39- \\
1.00)\end{array}$ & 0.042 & $\begin{array}{c}0.64(0.40- \\
1.02)\end{array}$ & 0.053 \\
\hline \multirow{8}{*}{$\geq 55$} & \multirow[t]{8}{*}{ rs197452 } & \multirow[t]{3}{*}{ Codominant } & $\mathrm{C} / \mathrm{C}$ & $141(75.4 \%)$ & $\begin{array}{c}328 \\
(75.9 \%)\end{array}$ & 1 & 0.97 & 1 & 0.96 \\
\hline & & & $\mathrm{C} / \mathrm{T}$ & $42(22.5 \%)$ & $94(21.8 \%)$ & $\begin{array}{c}0.96(0.64- \\
1.46)\end{array}$ & & $\begin{array}{c}0.95(0.63- \\
1.44)\end{array}$ & \\
\hline & & & $\mathrm{T} / \mathrm{T}$ & $4(2.1 \%)$ & $10(2.3 \%)$ & $\begin{array}{c}1.07(0.33- \\
3.48)\end{array}$ & & $\begin{array}{c}1.09(0.33- \\
3.53)\end{array}$ & \\
\hline & & \multirow[t]{2}{*}{ Dominant } & $\mathrm{C} / \mathrm{C}$ & $141(75.4 \%)$ & $\begin{array}{c}328 \\
(75.9 \%)\end{array}$ & 1 & 0.89 & 1 & 0.86 \\
\hline & & & $\mathrm{C} / \mathrm{T}-\mathrm{T} / \mathrm{T}$ & $46(24.6 \%)$ & $\begin{array}{c}104 \\
(24.1 \%)\end{array}$ & $\begin{array}{c}0.97(0.65- \\
1.45)\end{array}$ & & $\begin{array}{c}0.97(0.65- \\
1.44)\end{array}$ & \\
\hline & & \multirow[t]{2}{*}{ Recessive } & $\mathrm{C} / \mathrm{C}-\mathrm{C} / \mathrm{T}$ & $183(97.9 \%)$ & $\begin{array}{c}422 \\
(97.7 \%)\end{array}$ & 1 & 0.89 & 1 & 0.88 \\
\hline & & & $\mathrm{T} / \mathrm{T}$ & $4(2.1 \%)$ & $10(2.3 \%)$ & $\begin{array}{c}1.08(0.34- \\
3.50)\end{array}$ & & $\begin{array}{c}1.10(0.34- \\
3.55)\end{array}$ & \\
\hline & & Log-additive & --- & --- & --- & $\begin{array}{c}0.99(0.69- \\
1.40)\end{array}$ & 0.94 & $\begin{array}{c}0.98(0.69- \\
1.39)\end{array}$ & 0.92 \\
\hline
\end{tabular}

$p<0.05$, statistical significance.

CAD in less than 50 years old group (rs197452: $\mathrm{OR}=0.63$, $95 \%$ CI: $0.39-1.00, p=0.042$ ). While in more than 50 years old group, we did not find significant results (Table 6).

Only one block was detected in the analysis using haploview software. The block consisted of rs1801157, rs266089, rs197452 and rs2839693 (Figure 1). The result of the association between $C X C L 12$ haplotype and CAD risk were listed in Table 7 . We found that haplotype "TGCC" in the block increased CAD risk $(\mathrm{OR}=1.26$, 95\%CI: $1.00-1.58, p=0.046$ ) (Table 7). While there was no statistical valid after adjusting age and sex.

\section{DISCUSSION}

It is widely acknowledged that hereditary factors contribute importantly to the risk of CAD and a large amount of genes and SNPs have been identified to be associated with $\mathrm{CAD}$ in various races $[15,16]$. In the current study, we detected 6 SNPs to identify the relationship between CAD and CXCL12 and found three (rs1065297, rs266089 and rs10793538) significant SNPs. As far as we known, these 3 SNPs were first reported to be associated with CAD risk. 
Table 7: $C X C L 12$ haplotype frequencies and their association with CAD

\begin{tabular}{lccccc}
\hline Haplotype & Freq & case & control & OR (95\% CI) & $p$-value \\
\hline CGCC & 0.4943 & 0.476 & 0.51 & 1.00 & -- \\
TGCC & 0.2131 & 0.217 & 0.21 & $1.10(0.90-1.35)$ & 0.34 \\
CACT & 0.1532 & 0.167 & 0.141 & $1.26(1.00-1.58)$ & 0.046 \\
CGTC & 0.1158 & 0.116 & 0.116 & $1.06(0.82-1.37)$ & 0.64 \\
CACC & 0.0212 & 0.024 & 0.019 & $1.29(0.75-2.21)$ & 0.36 \\
\hline
\end{tabular}

$p<0.05$, statistical significance.

GWAS reported that $S D F-1$ gene (CXCL-12), which located on 10q11.1 and involved in progenitor cell proliferation, traffic, adhesion and regulates cell survival, associated with cardiovascular disease susceptibility. We also found that rs266089 in CXCL12 gene increased the CAD risk in total population and in men; rs2839693 in CXCL12 gene associated with the risk of CAD in men. A study explored the $S D F 1$ SNPs for prognostic impact in patients with cardiovascular disease, found that cardiovascular who were $S D F 1$ rs2839693 and rs266089 minor allele carriers showed a significantly better event- free survival probability compared to homozygote carriers of major allele [17]. Apart from this, an article reported that homozygous genotype of the minor allele of rs2839693, A/A, was shown to be significantly decreased in ITP patients, which suggested a protective role of these genotypes [18].

Published studies have shown that the relationship between rs1801157 and CAD susceptibility exist inconsistent. Some studies suggested that rs1801157 in CXCL12 gene is not associated with the risk of coronary heart disease [19-21]. However, some studies have

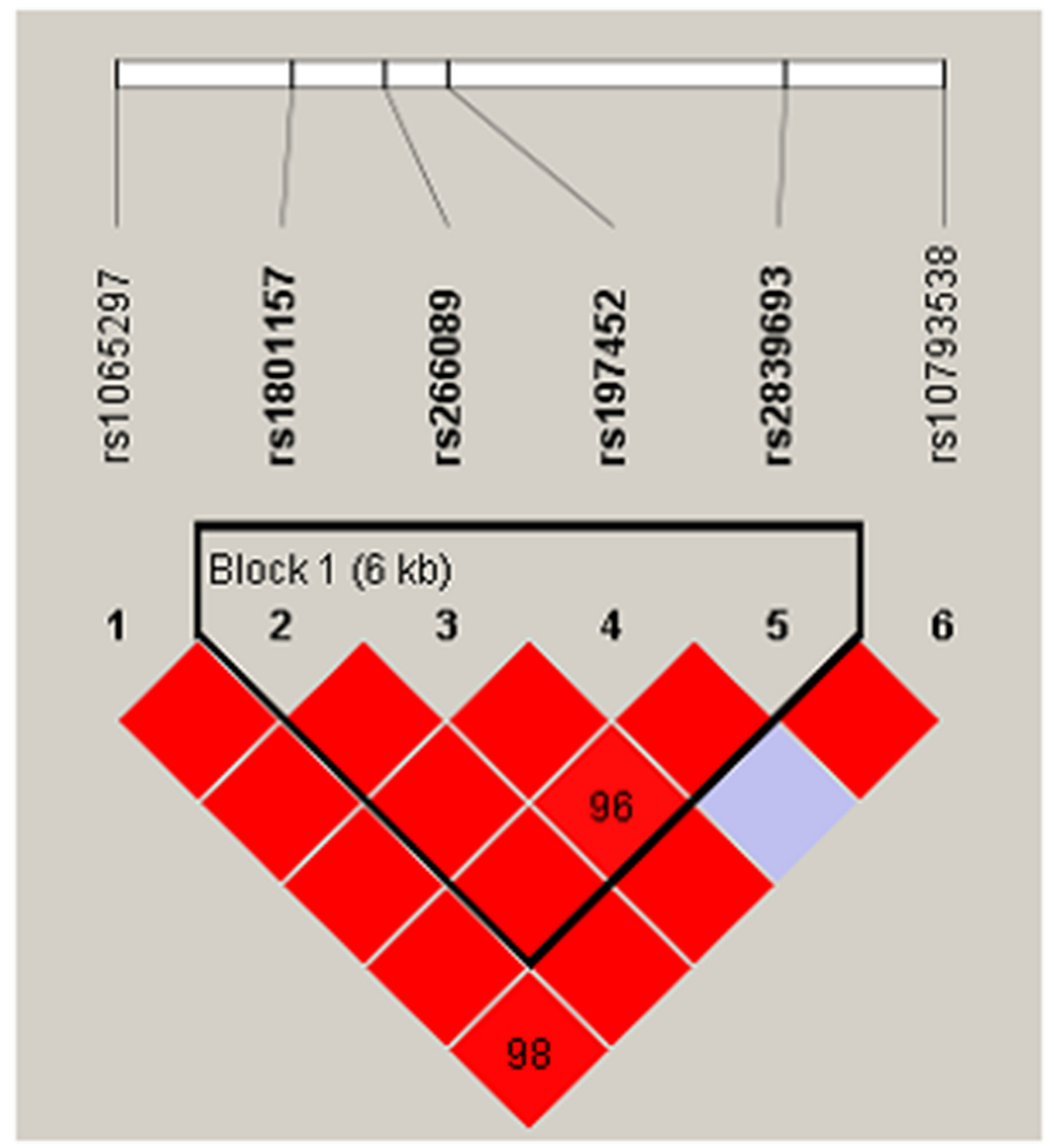

Figure 1: Haplotype block for the SNPs of CXCL12. 
suggested that $C X C L 12$ gene may affect the risk of coronary heart disease [22-25]. By integrating the results of other studies, meta-analysis showed that the rs 1801157 in $C X C L 12$ gene was not associated with the risk of coronary heart disease. In our research, we did not find the relationship between SNP rs1801157 and susceptibility to CAD. But, we found that significant differences in TP concentrations with rs1801157 different genotype.

Actually there were some limitations in our study. The sample volume of the case-control study (597 cases and 685 controls) was not relatively large enough. The most defect of our specimen was the mismatching of age and sex. It would still have some random error although in a certain extent though we indeed did some adjustment. The most useful way to solve the question we thought is to take them as independent factors. The main methods of controlling the confounding factors include restrictions on randomization, matching, stratified analysis, multivariate analysis. Due to the age and sex is not match, in the process of statistical analysis, ORs and $95 \%$ CIs were computed based on unconditional logistic regression adjusted by age and gender. In addition to, further stratified analysis by sex and age were performed to eliminate the influence of confounding factors.

Our findings in the case-control study provide new evidence for the relationship between SNPs and haplotype of CXCL12 with CAD risk. What is more, we found different influence of the SNPs between males and females. It's a pity that we did not clarify the mechanism of how the SNPs affect the risk of CAD but we thought it would be a new research direction in the future.

\section{MATERIALS AND METHODS}

\section{Ethics statement}

The protocol in this study conformed to the principles of the Declaration of Helsinki and was ratified by the Ethical Committee of the First Affiliated Hospital of Xi'an Jiaotong University Health Science Center, China. Signed informed consent was obtained from each participant.

\section{Study participants}

A total of 597 patients were recruited in the department of cardiology in First Affiliated Hospital of $\mathrm{Xi}$ 'an Jiaotong University from. At least two experienced cardiologists performed the diagnosis of CHD according to American Heart Association guidelines [26]. All patients were confirmed by the obstruction of at least 1 large epicardial coronary artery by atheromatous plaque using coronary angiography ( $>50 \%$ diameter stenosis in at least one of the major coronary arteries). Patients who met the exclusion criteria will be excluded from this study: alcohol abuse, diabetes, a history of smoking, chronic lung disease, xanthelasma, and evidence of noncoronary atherosclerotic disease. We also collected the clinical data of CAD patient, including Serum concentrations of ALT, AST, GGT, TP, GLU, TG, TC, HDL-C, LDL-C, APOA, APOB, Lp(a).

Additionally, there were in total 708 relative healthy controls in other departments were involved but 23 were excluded for the defective information or the poor DNA quality. Eventually, 597 case groups and 685 control groups with informed consent were taken into consideration to explore the association between the 6 SNPs and CAD. All the subjects were Chinese Han people and the information was collected by the medical records.

\section{SNP selection and genotyping}

We selected candidate SNPs of CXCL12 according to previous published papers which demonstrated association with CAD in other ethnic lines and only $\mathrm{MAF}>5 \%$ in the Hapmap Asian population were valid [17]. Finally, a number of 6 SNPs were chosen for further analysis. Genomic DNA extracted and concentrated were accomplished using GoldMag-Mini Purification Kit (GoldMag Co. Ltd. Xian city, China) and spectrometry (DU530 UV/VIS spectrophotometer, Beckman Instruments, Fullerton, CA, USA), respectively. Sequenom MassARRAY RS1000 was applied to genotype the candidate SNPs and subsequently data management and analysis were performed by the Sequenom Typer 4.0 Software [27].

\section{Statistical analysis}

For continuous variable, presented as means \pm standard deviations (SDs), performed by T-test; for categorical variables performed by Pearson's chi-square test. From variance analysis assess the differences in continuous variables among the subjects with three genotypes of related genes.

Hardy-Weinberg equilibrium (HWE) was performed for each SNP in control groups using exact test. The differences in allele and genotype frequencies for each SNP between cases and controls were detected using Pearson Chi-Square $\left(\chi^{2}\right)$ test [28]. ORs and $95 \%$ CIs were computed based on unconditional logistic regression [29]. Further stratified analysis by sex and age were performed to eliminate the influence of confounding factors. The four genetic models, dominant, co-dominant, recessive and logadditive were applied by PLINK software (http://pngu. mgh.harvard.edu/purcell/plink/) to evaluate the association between the SNPs and CAD.

Statistical analyses were performed using Microsoft Excel and PLINK software. And two-sided $p$-values < 0.05 were considered statistically significant. 


\section{ACKNOWLEDGMENTS}

We are grateful to all the patients and individuals in the study who made this work possible. We would also like to thank the clinicians and hospital staff who contributed to data collection for this study.

\section{CONFLICTS OF INTEREST}

The authors declare no conflicts of interest.

\section{REFERENCES}

1. GBD 2013 DALYs and HALE Collaborators, Murray CJ, Barber RM, Foreman KJ, Abbasoglu Ozgoren A, AbdAllah F, Abera SF, Aboyans V, Abraham JP, Abubakar I, Abu-Raddad LJ, Abu-Rmeileh NM, Achoki T, et al. Global, regional, and national disability-adjusted life years (DALYs) for 306 diseases and injuries and healthy life expectancy (HALE) for 188 countries, 1990-2013: quantifying the epidemiological transition. Lancet. 2015; 386:2145-2191.

2. Ross R, Glomset J, Harker L. Response to injury and atherogenesis. The American journal of pathology. 1977; 86:675-684

3. Wong ND. Epidemiological studies of CHD and the evolution of preventive cardiology. Nature reviews Cardiology. 2014; 11:276-289.

4. Baudhuin LM. Genetics of coronary artery disease: focus on genome-wide association studies. American journal of translational research. 2009; 1:221-234.

5. Wakil SM, Ram R, Muiya NP, Mehta M, Andres E, Mazhar N, Baz B, Hagos S, Alshahid M, Meyer BF, Morahan G, Dzimiri N. A genome-wide association study reveals susceptibility loci for myocardial infarction/coronary artery disease in Saudi Arabs. Atherosclerosis. 2016; 245:62-70.

6. Pranavchand R, Reddy MM. Genomics era and complex disorders: Implications of GWAS with special reference to coronary artery disease, type 2 diabetes mellitus, and cancers. Journal of postgraduate medicine. 2016; 62:188-198.

7. Hartiala JA, Tang WH, Wang Z, Crow AL, Stewart AF, Roberts R, McPherson R, Erdmann J, Willenborg C, Hazen SL, Allayee H. Genome-wide association study and targeted metabolomics identifies sex-specific association of CPS1 with coronary artery disease. Nature communications. 2016; $7: 10558$.

8. Farouk SS, Rader DJ, Reilly MP, Mehta NN. CXCL12: a new player in coronary disease identified through human genetics. Trends in cardiovascular medicine. 2010; 20:204-209.

9. Akhtar S, Gremse F, Kiessling F, Weber C, Schober A. CXCL12 promotes the stabilization of atherosclerotic lesions mediated by smooth muscle progenitor cells in
Apoe-deficient mice. Arteriosclerosis, thrombosis, and vascular biology. 2013; 33:679-686.

10. Teicher BA, Fricker SP. CXCL12 (SDF-1)/CXCR4 pathway in cancer. Clinical cancer research. 2010; 16:2927-2931.

11. van der Vorst EP, Doring Y, Weber C. MIF and CXCL12 in Cardiovascular Diseases: Functional Differences and Similarities. Front Immunol. 2015; 6:373.

12. Albert S, Riveiro ME, Halimi C, Hourseau M, Couvelard A, Serova M, Barry B, Raymond E, Faivre S. Focus on the role of the CXCL12/CXCR4 chemokine axis in head and neck squamous cell carcinoma. Head \& neck. 2013; 35:1819-1828.

13. Abe-Suzuki S, Kurata M, Abe S, Onishi I, Kirimura S, Nashimoto M, Murayama T, Hidaka M, Kitagawa M. CXCL12+ stromal cells as bone marrow niche for CD34+ hematopoietic cells and their association with disease progression in myelodysplastic syndromes. Laboratory investigation. 2014; 94:1212-1223.

14. Serrano-Pertierra E, Blanco-Gelaz MA, Oliva-Nacarino P, Martinez-Camblor P, Villafani J, Lopez-Larrea C, CernudaMorollon E. Increased natural killer cell chemotaxis to CXCL12 in patients with multiple sclerosis. Journal of neuroimmunology. 2015; 282:39-44.

15. Myocardial Infarction Genetics Consortium, Kathiresan S, Voight BF, Purcell S, Musunuru K, Ardissino D, Mannucci PM, Anand S, Engert JC, Samani NJ, Schunkert H, Erdmann J, Reilly MP, et al. Genome-wide association of early-onset myocardial infarction with single nucleotide polymorphisms and copy number variants. Nature genetics. 2009; 41:334-341.

16. Samani NJ, Erdmann J, Hall AS, Hengstenberg C, Mangino M, Mayer B, Dixon RJ, Meitinger T, Braund P, Wichmann HE, Barrett JH, Konig IR, Stevens SE, et al. Genomewide association analysis of coronary artery disease. The New England journal of medicine. 2007; 357:443-453.

17. Rath D, Schaeffeler E, Winter S, Hewer J, Muller K, Droppa M, Stimpfle F, Gawaz M, Schwab M, Geisler T. SDF1 Polymorphisms Influence Outcome in Patients with Symptomatic Cardiovascular Disease. PLoS One. 2016; 11:e0161933.

18. Ku FC, Tsai CR, Der Wang J, Wang CH, Chang TK, Hwang WL. Stromal-derived factor-1 gene variations in pediatric patients with primary immune thrombocytopenia. European Journal of Haematology. 2013; 90:25-30.

19. Apostolakis S, Baritaki S, Kochiadakis GE, Igoumenidis NE, Panutsopulos D, Spandidos DA. Effects of polymorphisms in chemokine ligands and receptors on susceptibility to coronary artery disease. Thromb Res. 2007; 119:63-71.

20. Szalai C, Duba J, Prohaszka Z, Kalina A, Szabo T, Nagy B, Horvath L, Csaszar A. Involvement of polymorphisms in the chemokine system in the susceptibility for coronary artery disease (CAD). Coincidence of elevated Lp(a) and MCP-1 
$-2518 \mathrm{G} / \mathrm{G}$ genotype in CAD patients. Atherosclerosis. 2001; 158:233-239.

21. Liu J, Jia YJ, Li XL, Xu RX, Zhu CG, Guo YL, Wu NQ, Li JJ. RANTES gene G-403A polymorphism and coronary artery disease: a meta analysis of observational studies. PLoS One. 2012; 7:e47211.

22. Gu XL, Ma N, Xiang DC, Huang J, Dong ZH, Lei HY, Ding R, Gong ZH, Wen YF, Qiu J, Ma L. Polymorphism of stromal cell-derived factor-1 selectively upregulates gene expression and is associated with increased susceptibility to coronary artery disease. Biochemical and biophysical research communications. 2014; 443:932-937.

23. Luan B, Han Y, Zhang X, Kang J, Yan C. Association of the SDF1-3'A polymorphism with susceptibility to myocardial infarction in Chinese Han population. Molecular biology reports. 2010; 37:399-403.

24. Borghini A, Sbrana S, Vecoli C, Mercuri A, Turchi S, Carpeggiani C, L'Abbate A, Andreassi MG. Stromal cell-derived factor-1-3'A polymorphism is associated with decreased risk of myocardial infarction and early endothelial disturbance. Journal of cardiovascular medicine (Hagerstown, Md). 2014; 15:710-716.

25. Feng L, Nian SY, Hao YL, Xu WB, Ye D, Zhang XF, Li D, Zheng L. A single nucleotide polymorphism in the stromal cell-derived factor 1 gene is associated with coronary heart disease in Chinese patients. Int J Mol Sci. 2014; 15:11054-11063.

26. Smith SC Jr, Benjamin EJ, Bonow RO, Braun LT, Creager MA, Franklin BA, Gibbons RJ, Grundy SM, Hiratzka LF, Jones DW, Lloyd-Jones DM, Minissian M, Mosca L, et al. AHA/ACCF secondary prevention and risk reduction therapy for patients with coronary and other atherosclerotic vascular disease: 2011 update: a guideline from the American Heart Association and American College of Cardiology Foundation endorsed by the World Heart Federation and the Preventive Cardiovascular Nurses Association. J Am Coll Cardiol. 2011; 58:2432-2446.

27. Trembizki E, Smith H, Lahra MM, Chen M, Donovan B, Fairley CK, Guy R, Kaldor J, Regan D, Ward J, Nissen MD, Sloots TP, Whiley DM. High-throughput informative single nucleotide polymorphism-based typing of Neisseria gonorrhoeae using the Sequenom MassARRAY iPLEX platform. The Journal of antimicrobial chemotherapy. 2014; 69:1526-1532.

28. Adamec C. [Example of the use of the nonparametric test. Test X2 for comparison of 2 independent examples]. [Article in Czech]. Cesk Zdrav. 1964; 12:613-9.

29. Bland JM, Altman DG. Statistics notes. The odds ratio. BMJ (Clinical research ed). 2000; 320:1468. 